\title{
Inventory - an innovative area of research and implementation of RFID technology
}

\author{
Michał Grabia, Tomasz Janiak
}

Since its inception, the Institute of Logistics and Warehousing in Poznan has focused its research potential issues related to logistics and storage in a broad sense. One of the most common processes in this area, which we can actually meet both in business environments and in every household, is inventory.

A »physical « inventory of available material resources and registration of results of this activity is a process that dates back to the ancient past. According to archaeologists, the clay tablet considered Europe's oldest written text, found in the ruins of the Mycenaean buildings in a small Greek village Iklaina on Peloponnese, is the list of someone's property, which was probably made between 1450-1350 BC. Similar artefacts have also been found in the ruins of other ancient cultures around the world.

In the past few years, the inventory process has undergone a major evolution, which we generally owe exclusively to the development of automatic identification technologies. Inventory activities, which were originally performed based on visual identification and manual registration of results on a sheet of paper, have been improved through the introduction of barcodes and portable scanners/terminals directly connected to the data collection systems. In addition, in recent years the world has seen this process subjected to further improvements through the introduction of even more advanced automatic identification techniques based on radio waves - RFID.

The area of potential applications of RFID technology is very wide, but unlike barcodes, the application of this technique also has some limitations. Not all of the objects and environments are equally friendly to radio waves. Placing RFID tags on containers with liquids or on metal objects or even the installation of the system in areas with harsh environmental conditions (such as interference from electric motors, collisions with other RFID systems or with a large number of objects made of metal) can sometimes be a problem.

Accordingly, in recent years, there is a significant increase in the number of implementations, but only in certain industries, in which problems with the implementation of RFID are practically absent or minimal. The group of such areas, which were the first to take the challenge of implementing this technology, includes libraries and archives.

Libraries were the one of the first institutions to initiate the process of adapting ADC technology to their needs. At the moment, a lot of libraries in Europe and around the world use the ability to identify existing resources based on the reading of RFID tags placed on the books. So far, most of them concentrated on the use of RFID technology operating in high frequency - HF. Recently, however, we hear more and more often about the implementation of new solutions based on the UHF band. 
The reason for this seems to be obvious. The first UHF solutions were not perfect and had many weaknesses. The effectiveness of these systems left much to be desired. In addition, there was also no possibility of an easy use of RFID tags in both the management of books and magazines (such as renting, returns, etc.) while simultaneously carrying out anti-theft EAS functions (Electronic Article Surveillance).

Recent RFID solutions no longer have this problem, and additionally due to the shape of the tag, they allow for more effective securing of books. An oblong, relatively narrow RFID UHF transponder can be pasted between the pages right at the back of the book in such a way that finding it may be a problem even for the person who placed it there. Inability to locate the tag also protects the book against intrusion of the reader and ultimately an attempt of its theft.

Also in the area of inventory, the new technology has introduced new opportunities, which, in comparison with both the classical method (visual identification combined with manual registration on sheets of paper) or using barcodes allows for achieving a completely new quality, especially in regard to the time required to perform the actual physical inventory, which in the case of RFID applications has been significantly reduced, and results from the fact of not having to see the label placed on the marked object.

As part of research carried out at the Institute of Logistics and Warehousing, the measurements of time required to complete the inventory were performed using two different techniques of automatic identification. An independent team of ILiM employees marked the selected objects in randomly selected rooms of the Institute. Subsequently, four independent testers carried out a physical inventory in all these rooms by using two selected identification techniques (barcode and RFID). Due to the need to eliminate the possibility of remembering which objects have been marked, each tester first conducted an inventory only using barcodes. It was only after the measurement of time in all the rooms that the test was repeated with the use of radio frequency technology for the identification of objects - RFID.

The obtained results clearly confirm that the use of RFID will significantly reduce the time needed for the implementation of inventory activities. The study shows that the inventory based on RFID may be performed even up to $80 \%$ faster than using barcodes [Tab. 1].

\begin{tabular}{|c|c|c|c|c|c|c|c|c|c|c|}
\hline \multirow[t]{2}{*}{$\begin{array}{l}\text { No. } \\
\text { Meas. }\end{array}$} & \multirow{2}{*}{$\begin{array}{l}\text { Num- } \\
\text { ber of } \\
\text { tagged } \\
\text { objects }\end{array}$} & \multirow{2}{*}{$\begin{array}{l}\text { ADC } \\
\text { techno- } \\
\text { logy }\end{array}$} & \multicolumn{4}{|c|}{$\begin{array}{l}\text { Inventory time by individual testers } \\
\text { [mm:ss] }\end{array}$} & \multirow{2}{*}{$\begin{array}{l}\text { Average } \\
\text { inventory } \\
\text { time } \\
{[\mathrm{mm}: \mathrm{ss}]}\end{array}$} & \multirow[t]{2}{*}{$\begin{array}{l}\text { Standard } \\
\text { deviation }\end{array}$} & \multirow[t]{2}{*}{ Profit } & \multirow{2}{*}{$\begin{array}{l}\text { Average } \\
\text { single } \\
\text { object scan- } \\
\text { ning time } \\
\text { [mm: ss] }\end{array}$} \\
\hline & & & $\begin{array}{l}\text { Person } \\
1\end{array}$ & $\begin{array}{l}\text { Person } \\
2\end{array}$ & $\begin{array}{l}\text { Person } \\
3\end{array}$ & $\begin{array}{l}\text { Person } \\
4\end{array}$ & & & & \\
\hline \multirow[t]{2}{*}{ A } & \multirow[t]{2}{*}{61} & Barcodes & 07:52.0 & & & & & & \multirow[t]{2}{*}{$80 \%$} & \\
\hline & & RFID & 01:06.0 & 02:07.0 & $01: 13.0$ & $01: 35.0$ & $01: 30.3$ & 0.000318 & & \\
\hline \multirow[t]{2}{*}{ B } & \multirow[t]{2}{*}{47} & Barcodes & 06:27.0 & 06:15.0 & $07: 28.0$ & $06: 45.0$ & $06: 43.8$ & 0.000370 & \multirow[t]{2}{*}{$75 \%$} & \\
\hline & & RFID & \begin{tabular}{|l|}
$01: 37.0$ \\
\end{tabular} & 01:47.0 & $01: 29.0$ & $01: 45.0$ & $01: 39.5$ & 0.000095 & & $00: 02.1$ \\
\hline \multirow[t]{2}{*}{$C$} & \multirow[t]{2}{*}{30} & Barcodes & $04: 19.0$ & $03: 23.0$ & 03:06.0 & $02: 49.0$ & $03: 24.2$ & 0.000452 & \multirow[t]{2}{*}{$71 \%$} & $00: 06.8$ \\
\hline & & RFID & $01: 30.0$ & $00: 45.0$ & $00: 53.0$ & $00: 48.0$ & 00:59.0 & 0.000242 & & $00: 02.0$ \\
\hline
\end{tabular}




\begin{tabular}{|c|c|c|c|c|c|c|c|c|c|c|}
\hline \multirow[t]{2}{*}{$\begin{array}{l}\text { No. } \\
\text { Meas. }\end{array}$} & \multirow{2}{*}{$\begin{array}{l}\text { Num- } \\
\text { ber of } \\
\text { tagged } \\
\text { objects }\end{array}$} & \multirow{2}{*}{$\begin{array}{l}\text { ADC } \\
\text { techno- } \\
\text { logy }\end{array}$} & \multicolumn{4}{|c|}{$\begin{array}{l}\text { Inventory time by individual testers } \\
\text { [mm:ss] }\end{array}$} & \multirow{2}{*}{$\begin{array}{l}\text { Average } \\
\text { inventory } \\
\text { time } \\
\text { [mm:ss] }\end{array}$} & \multirow[t]{2}{*}{$\begin{array}{l}\text { Standard } \\
\text { deviation }\end{array}$} & \multirow[t]{2}{*}{ Profit } & \multirow{2}{*}{$\begin{array}{l}\text { Average } \\
\text { single } \\
\text { object scan- } \\
\text { ning time } \\
\text { [mm: ss] }\end{array}$} \\
\hline & & & $\begin{array}{l}\text { Person } \\
1\end{array}$ & $\begin{array}{l}\text { Person } \\
2\end{array}$ & $\begin{array}{l}\text { Person } \\
3\end{array}$ & $\begin{array}{l}\text { Person } \\
4\end{array}$ & & & & \\
\hline \multirow[t]{2}{*}{$\mathrm{D}$} & \multirow[t]{2}{*}{16} & Barcodes & $01: 49.0$ & $02: 27.0$ & $02: 35.0$ & $02: 42.0$ & $02: 23.3$ & 0.000274 & \multirow[t]{2}{*}{$77 \%$} & $00: 09.0$ \\
\hline & & RFID & $00: 30.0$ & $00: 50.0$ & $00: 23.0$ & $00: 29.0$ & $00: 33.0$ & 0.000136 & & $00: 02.1$ \\
\hline \multirow[t]{2}{*}{$\mathrm{E}$} & \multirow[t]{2}{*}{20} & Barcodes & $02: 13.0$ & $01: 24.0$ & $02: 16.0$ & $02: 05.0$ & $01: 59.5$ & 0.000279 & \multirow[t]{2}{*}{$60 \%$} & $00: 06.0$ \\
\hline & & RFID & $00: 30.0$ & $00: 44.0$ & $01: 00.0$ & $00: 58.0$ & $00: 48.0$ & 0.000161 & & $00: 02.4$ \\
\hline \multirow[t]{2}{*}{$F$} & \multirow[t]{2}{*}{8} & Barcodes & $00: 30.0$ & $00: 39.0$ & $01: 10.0$ & $00: 33.0$ & $00: 43.0$ & 0.000213 & \multirow[t]{2}{*}{$60 \%$} & $00: 05.4$ \\
\hline & & RFID & $00: 10.0$ & $00: 13.0$ & $00: 15.0$ & $00: 31.0$ & $00: 17.3$ & 0.000109 & & $00: 02.2$ \\
\hline
\end{tabular}

Tab. 1: The results of the measurements of inventory time

In addition, as part of the study, tests were carried out on the dependence of the time needed to carry out an inventory on the number of objects tagged (test rooms contained different numbers of tagged objects). The results of the study are clear and allow for proposing a thesis that the effect of time reduction of an inventory is greater with the increase in the number of tagged objects. As a result, we could be tempted to say that the higher the number of tagged objects, the shorter the physical inventory using RFID, in comparison to the use of classical barcodes [Fig. 1].

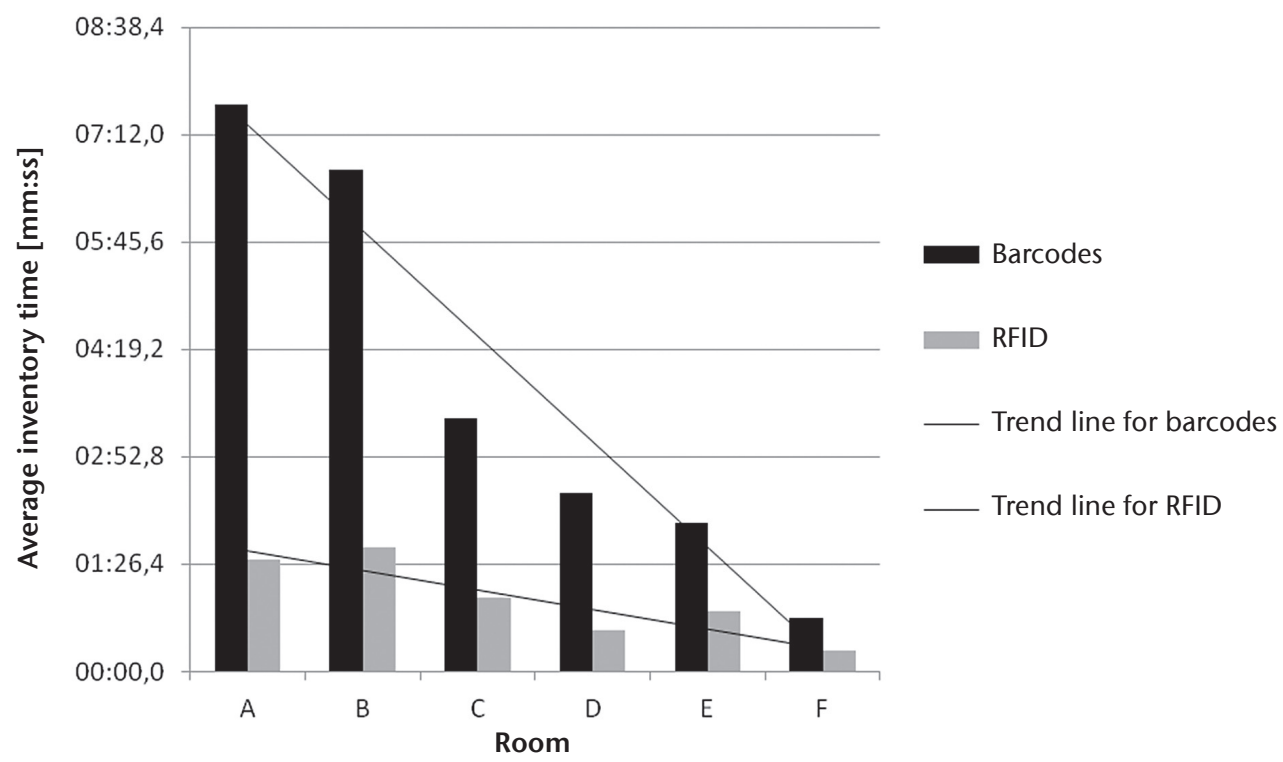

Fig. 1 Comparison of the duration of the inventory process carried out in selected test rooms using two different techniques of automatic identification (barcodes and RFID)

The results obtained were the basis to undertake further work at the ILiM on the potential use of RFID technology in the inventory process. In the course of the »Use Case Analysis « carried out on the use of RFID in inventory, we identified a number of situations that have never been taken into account (in the context of the use of classical methods or barcodes) and which may occur only in the case of RFID applications [Tab. 2]. 


\begin{tabular}{|c|c|c|c|c|c|c|}
\hline \multirow[t]{2}{*}{ No. } & \multicolumn{2}{|c|}{$\begin{array}{l}\text { Data on the terminal } \\
\text { application }\end{array}$} & \multirow{2}{*}{$\begin{array}{l}\text { Factual } \\
\text { circumstances } \\
\text { Object present? }\end{array}$} & \multirow[t]{2}{*}{ Comment } & \multicolumn{2}{|l|}{ Reaction } \\
\hline & Tag reading & Expected & & & $\begin{array}{l}\text { Reaction of the } \\
\text { application }\end{array}$ & User reaction \\
\hline 1 & No & No & No & $\begin{array}{l}\text { Typical situation, the } \\
\text { object is not there. }\end{array}$ & None & None \\
\hline 2 & No & No & Yes & $\begin{array}{l}\text { Tag damaged, the object } \\
\text { has been moved }\end{array}$ & None & $\begin{array}{l}\text { Entry in the } \\
\text { notebook }\end{array}$ \\
\hline 3 & No & Yes & No & $\begin{array}{l}\text { Typical situation, the } \\
\text { object has been moved }\end{array}$ & $\begin{array}{l}\text { On the list of } \\
\text { expected objects }\end{array}$ & None \\
\hline 4 & No & Yes & Yes & Tag damaged & $\begin{array}{l}\text { On the list of } \\
\text { expected objects }\end{array}$ & $\begin{array}{l}\text { Entry in the } \\
\text { notebook }\end{array}$ \\
\hline 5 & Yes & No & No & $\begin{array}{l}\text { Tag reading through } \\
\text { the wall }\end{array}$ & $\begin{array}{l}\text { On the list of } \\
\text { redundant objects }\end{array}$ & $\begin{array}{l}\text { Cancelled } \\
\text { reading }\end{array}$ \\
\hline 6 & Yes & No & Yes & $\begin{array}{l}\text { Typical situation, the } \\
\text { object has been moved }\end{array}$ & $\begin{array}{l}\text { On the list of } \\
\text { redundant objects }\end{array}$ & None \\
\hline 7 & Yes & Yes & No & $\begin{array}{l}\text { Object has been moved, } \\
\text { reading through the wall }\end{array}$ & $\begin{array}{l}\text { Removal from the } \\
\text { list of expected } \\
\text { objects }\end{array}$ & $\begin{array}{l}\text { Cancelling the } \\
\text { reading }\end{array}$ \\
\hline 8 & Yes & Yes & Yes & Typical situation. & $\begin{array}{l}\text { Removal from the } \\
\text { list of expected } \\
\text { objects }\end{array}$ & None \\
\hline
\end{tabular}

Tab. 2: Identified use cases for the inventory application using RFID technology

Of particular interest is a situation in which the person performing the physical inventory accidentally identifies an object located in another room (through the wall). Until now, such an event would practically never occur. The system solution created at the ILiM would therefore have to not only allow handling such an unusual situation but at the same time meet the other requirements identified by the persons who normally carry out inventories. The table below lists the additional features of the system created, based on interviews with persons responsible for carrying out inventories [Tab. 3].

\begin{tabular}{|l|l|l|}
\hline No. & Requirement & Justification \\
\hline 1 & $\begin{array}{l}\text { Physical inventory should be carried out } \\
\text { using just the terminal. }\end{array}$ & $\begin{array}{l}\text { No need to use (and carry) additional devices, such as } \\
\text { notebook. }\end{array}$ \\
\hline 2 & $\begin{array}{l}\text { The terminal should handle barcodes and } \\
\text { RFID. }\end{array}$ & $\begin{array}{l}\text { Ability to identify an object in case of problems with the } \\
\text { identification of RFID tags. }\end{array}$ \\
\hline 3 & $\begin{array}{l}\text { The terminal should work without being } \\
\text { connected to WLAN. }\end{array}$ & Ability to conduct an inventory in areas without wireless access. \\
\hline 4 & $\begin{array}{l}\text { Terminals should synchronise via WLAN } \\
\text { whenever possible. }\end{array}$ & $\begin{array}{l}\text { The ability to coordinate the inventory, for example, warning } \\
\text { against inventorying the same room twice. }\end{array}$ \\
\hline 5 & $\begin{array}{l}\text { The terminal should operate as far as } \\
\text { possible without a stylus. }\end{array}$ & More comfortable to use. \\
\hline 6 & $\begin{array}{l}\text { Objects can be described using definable } \\
\text { attributes. }\end{array}$ & $\begin{array}{l}\text { Assigning objects (including fixed assets) to individual } \\
\text { organisational units, people, or the ability to create own } \\
\text { vocabulary of criteria. }\end{array}$ \\
\hline 7 & $\begin{array}{l}\text { The system should allow for the storage of } \\
\text { photographs of tagged objects. }\end{array}$ & $\begin{array}{l}\text { More comfortable to use in case of problems with finding an } \\
\text { object based on its name or description. }\end{array}$ \\
\hline
\end{tabular}

Tab. 3: List of inventory system requirements created on the basis of interviews with persons carrying out the inventory.

The requirements collected become the basis for defining the system architecture. The inventory process makes it necessary to implement an application for computers, allowing for management of the physical inventory, and a terminal application, running on 
handheld RFID readers. To make these two applications independent of each other, that is to allow the operation of one without the other, as well as the simultaneous operation of multiple instances of the application, it was decided to add an intermediate layer consists of a database together with mechanisms for sharing and synchronising data [Fig. 2]. The intermediate layer is installed on any computer (or in case of heavy load, on the appropriate server) and is activated for the duration of inventory process.

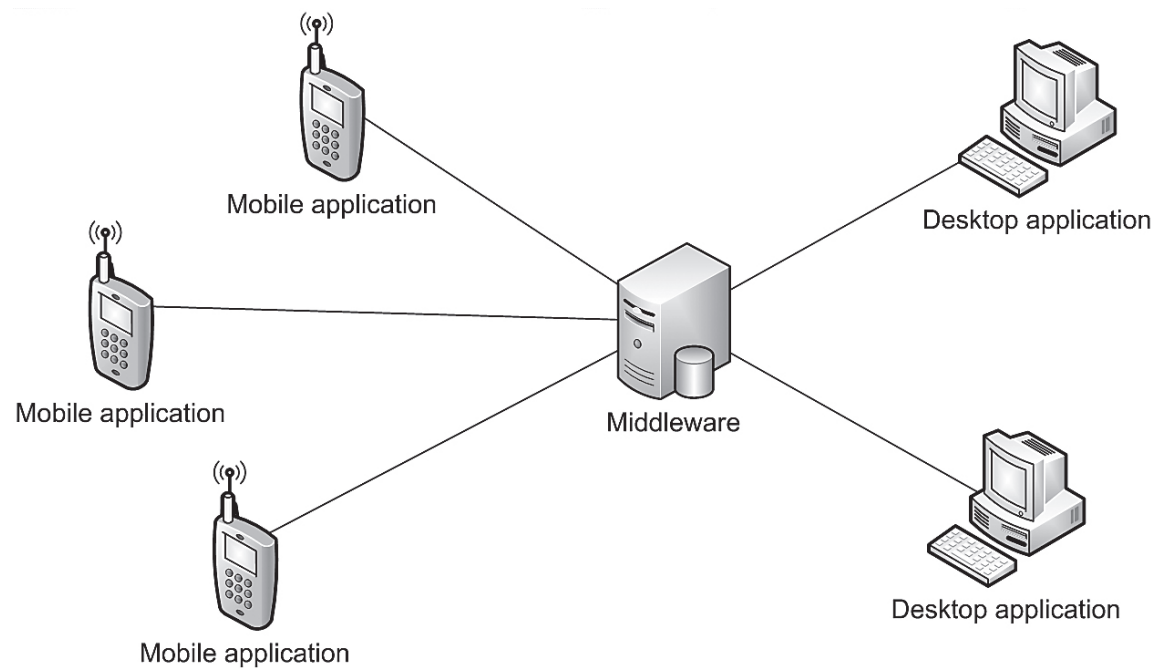

Fig. 2: Diagram of the system architecture.

In addition to functional requirements that define the utility value of a component of the IT inventory system, a reconnaissance of the RFID technology itself was carried out as part of the study. Tests of selected RFID tags were conducted, in the context of their applicability to tag the inventoried objects. The following transponders were chosen for testing:

1. UHF Rafsec G2 242_1 $20 \mathrm{~mm}$ x $40 \mathrm{~mm}$.

2. UHF Rafsec G2 163_2 $56 \mathrm{~mm}$ x $86 \mathrm{~mm}$.

3. UPM Rafsec PD70_18_6.

4. Alien 1800047.

5. Rafsec G2 $100 \mathrm{~mm} \times 15 \mathrm{~mm}$.

6. Rafsec G2 $100 \mathrm{~mm}$ x $20 \mathrm{~mm}$.

Tests of the reading range were performed using substrate inert to radio frequency (in this case it was a wooden substrate) in horizontal and vertical orientation, with the manual AT570 reader and the stationary Impinj reader (for comparison). The test results are shown in the table below [Tab. 4]. It is worth noting that the range of the manual reader is significantly smaller than the range of a desktop reader, which is further supported by the data contained in the specifications (maximum theoretical range of the MC9090-G reader is about $3 \mathrm{~m}$ ). This is related to the limited power of mobile devices resulting from the need to comply with the ETSI EN 300220 standard, and the fact of their limited energy resources (battery power supply). 


\begin{tabular}{|l|l|l|l|l|l|l|l|l|}
\hline No. & Manufacturer & Name/Type & $\begin{array}{l}\text { Tag } \\
\text { dimensions }\end{array}$ & $\begin{array}{l}\text { Label } \\
\text { dimensions }\end{array}$ & $\begin{array}{l}\text { Horizontally } \\
\text { AT570 }\end{array}$ & $\begin{array}{l}\text { AT570 } \\
\text { vertically }\end{array}$ & $\begin{array}{l}\text { Impinj } \\
\text { horizontally }\end{array}$ & $\begin{array}{l}\text { Impinj } \\
\text { vertically }\end{array}$ \\
\cline { 4 - 9 } & & & {$[\mathrm{mm}]$} & {$[\mathrm{mm}]$} & {$[\mathrm{cm}]$} & {$[\mathrm{cm}]$} & {$[\mathrm{cm}]$} & \\
{$[\mathrm{cm}]$}
\end{tabular}

Tab. 4: Results of tests on selected RFID tags.

The pool of tested RFID tags is defined both on the basis of the results of the reconnaissance as well as the results of previous studies of RFID technology, conducted at the ILiM. In the course of the study, we selected both tags possible to be applied in the form of paper labels as well as universal transponders, operating efficiently regardless of the substrate material on which are placed [Tab. 5].

\begin{tabular}{|l|l|l|l|l|l|l|l|l|l|}
\hline No. & Manufacturer & Name/Type & Dimensions & Wood & Metal & Glass & Cardboard & Polyethylene & Air \\
\cline { 4 - 9 } & & & {$[\mathrm{mm}]$} & {$[\mathrm{cm}]$} & {$[\mathrm{cm}]$} & {$[\mathrm{cm}]$} & {$[\mathrm{cm}]$} & {$[\mathrm{cm}]$} & {$[\mathrm{cm}]$} \\
\hline 1 & OmnilD & Flex & $97 / 21 / 6$ & 110 & 130 & 240 & 110 & 100 & 70 \\
\hline 2 & OmnilD & Prox & $55 / 16 / 8$ & 60 & 80 & 70 & 55 & 55 & 40 \\
\hline
\end{tabular}

Tab. 5: Results of tests on selected universal RFID tags.

Based on the results of the tests performed, we decided to select 4 types of tags for the tests of the inventory system. The selection took into account both the achieved reading range of the tags, as well as their size and the number of available samples:

1. UHF Rafsec G2 163_2 $56 \mathrm{~mm}$ x $86 \mathrm{~mm}$.

2. Rafsec G2 $100 \mathrm{~mm} \times 15 \mathrm{~mm}$.

3. UPM Raflatac Dog Bone $97 \mathrm{~mm} \times 27 \mathrm{~mm}$.

4. OmniID Flex $97 \mathrm{~mm} \times 21 \mathrm{~mm}$

First, it was decided to conduct an inventory of objects tagged only with tags placed underneath self-adhesive labels, so-called Smart Labels. This solution has certain advantages, such as:

- The possibility of printing over - as in the case of conventional labels.

- Low cost of the tag - depending on the model, several euro-cents apiece.

- High availability - a large variety of models offered by different suppliers.

- Small thickness - the label has dimensions similar to the dimensions of an ordinary labels without an RFID tag.

The tests confirmed that the main drawback of tags placed on labels is the high impact of the substrate on the effectiveness of their reading. Labels work well on material neutral for radio waves, such as wood, paper or plastic, but in practice they do not work at all when placed on a metal surface. For this reason, it is necessary to choose a different approach for the identification of metal objects. The analysis showed that, in principle, it is possible to take several courses of action: 
- More expensive tags dedicated to metal (tests were carried out using selected OmniID Flex tags).

- Separation of tags on labels from the substrate using a neutral layer, such as a cardboard backing.

- Placing tags on labels next to the tagged objects.

- Identification using barcodes only.

Each of these directions is always applicable and the decision to choose one of them, in the opinion of the research team, should always be left to the institution implementing the inventory solution being developed. One of such institutions, where a pilot implementation of the developed solution is currently taking place, is the Raczynski Library, operating in Poznan (Poland) since the beginning of the nineteenth century.

In the course of implementation, the library's fixed assets will be tagged with labels printed with a barcode and an RFID tag with EPC number programmed according to the GIAI standard (Global Individual Asset Identifier). A physical inventory will be carried out using a mobile terminal equipped with ATID 870 terminal equipped with a barcode reader and an RFID module. The inventory process will be started from the data synchronisation between the fixed assets database and the terminal, using a wireless network. In this way, the person conducting the inventory will be sure that the most recent data are used. Then, assets will be inventoried by reading RFID tags or barcodes printed on labels (a decision was made in the first phase of implementation to use barcode labels to tag all the objects made of metal). The solution implemented at the Raczynski Library allows the person performing the inventory to inspect the list of read, expected and redundant assets at any time, which greatly speeds up the work and allows for reducing the number of possible errors. After completing the inventory, the list of IDs read is sent to the system's central database. This allows for both viewing the inventory data from a computer, on which the desktop application is installed, generating reports on shortages, surpluses, inventory sheets, etc. in accordance with pre-defined templates. It also allows for exporting the results of the inventory to the financial and accounting application in order to make the necessary settlements.

The comprehensive software and hardware solution developed at the Institute of Logistics and Warehousing also has a number of other interesting features. In the desktop application, the following possibilities have been introduced, as expected by future users:

- User authentication [Fig. 3],

- Defining groups of users with different privileges,

- Work on multiple computers at the same time,

- Import of data from external sources (e.g. via Excel files, XML files, etc),

- Printing labels for assets and programming RFID tags,

- Editing fixed assets [Fig. 4],

- Reporting of inventories carried out [Fig. 5],

- Return to archival inventories,

- Adding attributes to fixed assets and their dictionaries, 


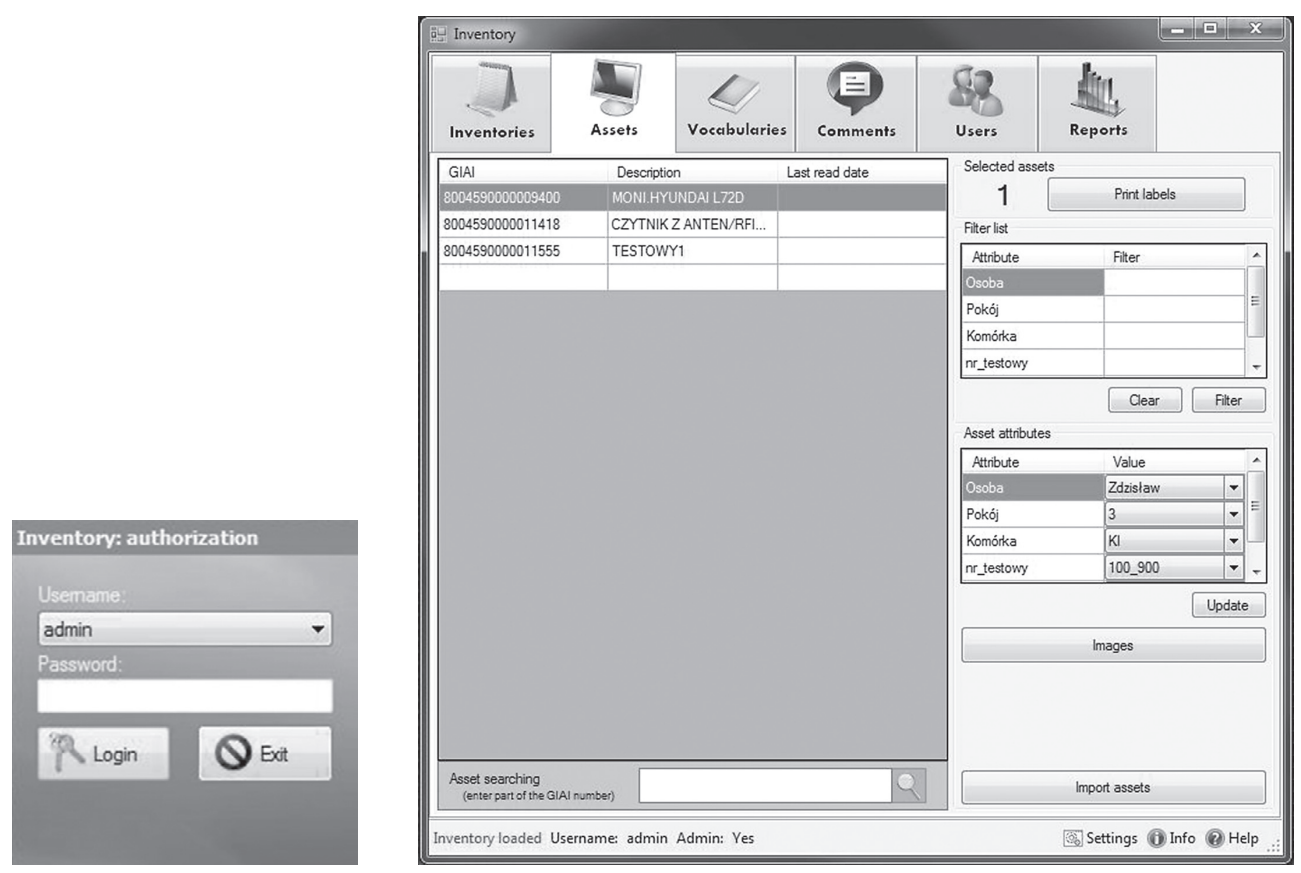

Fig. 3: Login screen of the computer application

Fig. 4: Asset viewing screen in the computer application

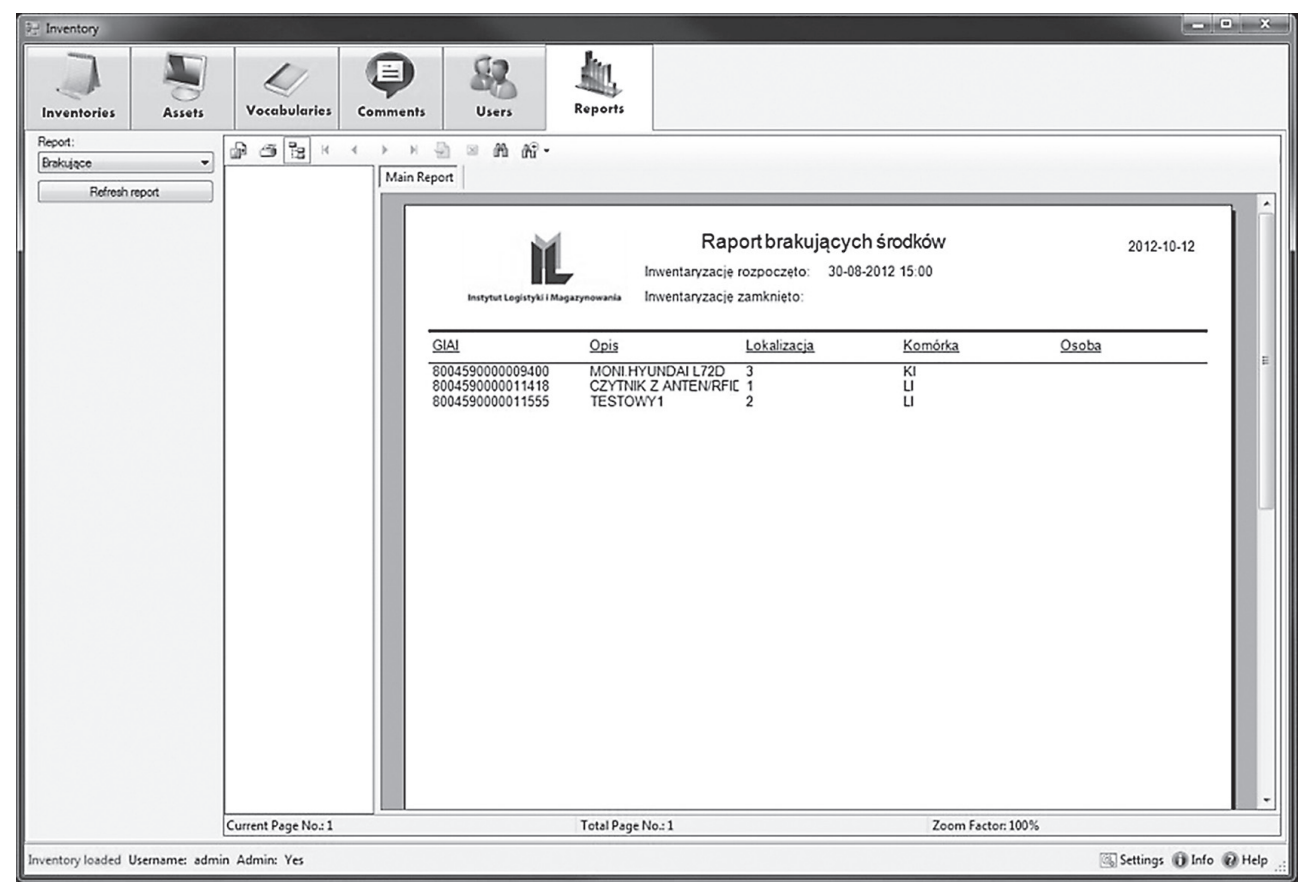

Fig. 5: Reporting screen in the computer application 
A number of specific features, which have been implemented as expected have also been identified in the terminal. The most important ones are:

- User authentication;

- Wireless sync with the current database of fixed assets;

- Identification of the selected fixed asset based on the reading of its barcode or RFID tag;

- Displaying detailed information about the selected fixed assets;

- Viewing pictures of fixed assets;

- Editing the attributes of fixed assets;

- Editing the attributes of location of fixed assets;

- Adding comments;

- Programming RFID tags;

- Search of an asset based on its number (for RFID tags only);

- Support for any terminal with Windows CE or Windows Mobile.

The combination of the two software components with hardware (RFID tags, terminals and printers) selected during the tests allows users to effectively and efficiently carry out all inventory processes. In libraries, this can apply to the fixed assets held and ultimately also books and magazines. The condition for such full use of the application is the use of the RFID UHF solution in the given library and not, as is quite often the case - the HF solution. Maintaining compatibility of the two solutions allows for much more efficient use of the solution developed at the ILiM and significantly strengthening the benefits of its implementation, which can include effects such as:

- Reducing inventory costs by shortening the time of its conduct;

- Shortening the duration of the inventory by up to four times using RFID tagged labels compared to markings with barcode alone;

- Reducing the number of people needed to carry out the inventory;

- Aesthetic marking of fixed assets or the possibility of hidden markings;

- The ability to quickly make changes to the status of the premises;

- Easy access to information and generating reports on the status of property;

- The possibility of frequent inventories.

\section{Summary}

The development of automatic identification technology has become an important stimulus for the improvement of the inventory process in a variety of industries. From the standpoint of practical applications, the universality of the described solution, which uses RFID technology, should be emphasised. In libraries, RFID-assisted inventory may be applied not only to the fixed assets held, but also the stored media (books, magazines, CDs). Pilot implementation of the application in one of the largest Polish libraries indicates a forward-looking nature of this solution and the benefits of effective time management. The use of RFID technology in libraries and archives allows for speeding up the work and reducing the number of mistakes, as evidenced by the tests conducted by the Institute of Logistics and Warehousing, confirming the reduced inventory times by up to $80 \%$ compared to the inventory with the use of barcodes. 